ORIGINAL ARTICLE

\title{
Correlation Between HCV RNA Viral Load And HOMA-IR In Chronic Hepatitis C Patients
}

\author{
Nadhya Allia ${ }^{*}$ (D), Poernomo Boedi Setiawan², Soebagijo Adi Soelistijo ${ }^{2}$ \\ ${ }^{1}$ Faculty of Medicine, Universitas Airlangga - Dr. Soetomo General Academic Hospital, Surabaya, Indonesia \\ ${ }^{2}$ Department of Internal Medicine, Faculty of Medicine - Dr. Soetomo General Academic Hospital, Surabaya, Indonesia
}

\begin{abstract}
A B S T R A C T
Introduction: Insulin resistance (IR) is one of the extrahepatic complications of hepatitis C virus (HCV) infection that needs to be recognized early. HOMA-IR is an effective way to measure insulin resistancy. Core proteins, NS-3, and NS-5 are the main components of HCV RNA proteins which are involved in the incidence of IR. Seeing this, a hypothesis was developed that the level of HCV RNA viral load was related to the HOMA-IR. This study was designed to identify the correlation between HCV RNA viral load with HOMA-IR in chronic hepatitis C patients.

Methods: We conducted a cross-sectional approach from the medical record of chronic hepatitis C patients at the outpatient clinic dr. Soetomo Hospital, Surabaya. A total of 30 patients aged $>19$ years old with complete medical records were included. Clinical and laboratory (including HCV RNA viral load level and HOMA-IR) data were obtained from the availability of medical records.

Results: A total of 30 chronic hepatitis C patients, 17 (56.7\%) were women and 13 (43.3\%) were men, with mean age was $50.90 \pm 7.17$ years. The median of HCV RNA viral load level was 3,14 x106 IU/ml and the median of HOMA-IR was 4.50. The result of the Spearman correlation test showed a moderate positive association between HCV RNA viral load and HOMA-IR ( $\mathrm{r}=0.537 ; \mathrm{p}=0.002)$.
\end{abstract}

Conclusion: A positive moderate correlation was obtained between HCV RNA viral load with HOMA-IR in chronic hepatitis C patients.

Keywords: Chronic hepatitis C, HCV RNA viral load, HOMA-IR

Correspondence: Nadhya Allia

E-mail: nadhyaallia@gmail.com

Article history: • Received 7 January $2020 \bullet$ Received in revised form 8 February $2021 \bullet$ Accepted 3 March 2021

\section{INTRODUCTION}

Hepatitis $\mathrm{C}$ virus (HCV) infection is an important cause of liver disease in the world. Recent data estimates that $2.8 \%$ of the world's population - more than 184 million people - are infected with HCV. In 2016, WHO estimates that 399,000 people died from hepatitis $\mathrm{C}$ with various complications (Jafri \& Gordon, 2018; Jefferies, 2018). Chronic hepatitis C is reported to be associated with a variety of diseases and complications, both intrahepatic and extrahepatic. Insulin resistance is one of the extrahepatic complications of $\mathrm{HCV}$ infection that needs to be recognized early because it can develop into other complications with serious consequences (Huang et al., 2011). HCV RNA protein is known to be involved in the development of insulin resistance in $\mathrm{HCV}$ infection (El-Zayadi \& Anis, 2012).

Epidemiological studies show chronic hepatitis $\mathrm{C}$ triggers insulin resistance by $25 \%$ which will accelerate the progression of liver fibrosis, resistance to anti-viral treatment, and the development of hepatocellular carcinoma (Mohamed et al., 2011, Bernsmeiere \& Heim, 2009; Mohamed HR et al., 2009; Bugianesi et al., 2005). Insulin resistance is a major pathogenetic factor of diabetes mellitus (DM) type 2 (Machado \& Cortez-Pinto, 2009).
Several studies have reported that chronic hepatitis $\mathrm{C}$ patients have a threefold increased risk of developing insulin resistance and DM compared to healthy individuals or patients with hepatitis B virus infection (Huang et al., 2011). Liver cirrhosis is a diabetogenic disease. The risk of DM in cirrhosis associated with $\mathrm{HCV}$ is 3 to 5 times greater than in cirrhosis associated with other causes. The prevalence of DM in the population affected by HCV infection without liver cirrhosis is around $7.6-21 \%$, which is 2 to 4 times higher than in other chronic hepatitis (White, 2008). One of the effective and efficient ways to measure insulin resistancy is the Homeostasis Model Assessment-Insulin Resistance (HOMA-IR) (Romero-Gomez, 2006).

The components of the HCV RNA protein that are mainly involved in the occurrence of insulin resistance are core protein, NS-3 protein, and NS-5A protein. HCV core protein induces TNF- $\alpha$ expression, decreases VLDL, increases lipogenesis, thereby inducing insulin resistance (El-Zayadi \& Anis, 2012). NS-3 protein has been shown to induce oxidative stress and increase NOX-2 regulation, thereby accelerating the production of ROS which ultimately leads to liver fibrosis and insulin resistance (Bureau et al., 2001). NS$5 \mathrm{~A}$ protein induces endoplasmic reticulum (ER) stress that 
leads to insulin resistance directly or indirectly by upregulation of the protein phosphatase 2A (PP2A) cellular gene (Christen et al., 2007). Looking at the involvement of HCV RNA protein components in the incidence of insulin resistance, a hypothesis was developed that the HCV RNA viral load was associated with an increased incidence of insulin resistance (Mohame et al., 2011).

The high prevalence of insulin resistance among patients with HCV infection has been consistently reported, and there is growing evidence to support this concept (Knobler et al., 2000; Mehta et al., 2000; Caronia et al., 1999; Mason et al., 1999). However, negative results regarding the association between HCV infection and insulin resistance have also been reported (Papatheodoridis et al., 2006; Mangia et al., 1998). The relationship between HCV RNA viral load and the incidence of insulin resistance remains controversial, while HCV RNA viral load examination is the initial routine check before starting therapy, so it is potential for screening insulin resistance in a large population of chronic hepatitis $\mathrm{C}$. This study aims to analyze the correlation between HCV RNA viral load and HOMA-IR in patients with chronic hepatitis $\mathrm{C}$ thus it can predict the occurrence of complications of $\mathrm{HCV}$ infection, predict outcome of therapy, and assess prognosis of the disease from an early stage.

\section{METHODS}

This analytical observational cross-sectional study was conducted in the gastrohepatology outpatient clinic Dr. Soetomo Teaching Hospital, Surabaya. All medical records of chronic hepatitis C patients from September 2016 to January 2017, aged $>19$ years old were analyzed.

All patients who has been diagnoses of chronic hepatitis $C$ and examined HCV RNA viral load, fasting blood glucose, and fasting insulin were included. Data of demographic, clinical, and laboratory were obtained from the availability of medical records. The study was approved by the Local Ethics Committee. All data analyzed statistically using SPSS version 23. For the normality test using the Kolmogorov-Smirnov test and then the data examined using Spearman correlation test.

\section{RESULTS}

A total of 30 subjects, 13 males (43.3\%) and 17 females (56.7\%), with chronic hepatitis C, aged $>19$ years old were analyzed as seen in table 1. Data that were normally distributed would be presented as mean $\pm \mathrm{SD}$, while data that were not normally distributed would be presented as median (minimum value-maximum value). The mean age of the study subjects was $50.90 \pm 7.17$ years, the youngest was 36 years old and the oldest was 59 years old.
From the characteristics of the laboratory results, the mean hemoglobin was $13.37 \pm 1.53 \mathrm{~g} \%$, the mean leukocyte was $5.670 \pm 1.725 / \mathrm{uL}$, and the mean platelet count was 187 $\pm 74.45 \times 10^{3} / \mathrm{uL}$. The mean value of AST was $86.70 \pm 52.49$ $\mathrm{U} / \mathrm{L}$ and the mean value of ALT was $78.63 \pm 38.88 \mathrm{U} / \mathrm{L}$. Bilirubin examination revealed a wide range data with an abnormal distribution. The direct bilirubin examination obtained the median value was $0.61 \mathrm{mg} / \mathrm{dL}$ with the lowest value was $0.11 \mathrm{mg} / \mathrm{dL}$ and the highest value was $2.03 \mathrm{mg} / \mathrm{dL}$. While the median of total bilirubin was $0.99 \mathrm{mg} / \mathrm{dL}$, with the lowest value was $0.27 \mathrm{mg} / \mathrm{dL}$ and the highest was 2.52 $\mathrm{mg} / \mathrm{dL}$. Blood albumin levels were still within normal limits with a mean of $3.95 \pm 0.31 \mathrm{~g} / \mathrm{L}$.

Table 1 Characteristic of Study Subjects

\begin{tabular}{ll}
\hline \multirow{2}{*}{ Variabel } & \multicolumn{1}{c}{$\mathrm{n}=30$} \\
\cline { 2 - 2 } & Mean $\pm \mathrm{SD}$ or Median (min-max) \\
\hline Age (years old) & $50.90 \pm 7.17$ \\
\hline Haemoglobin $(\mathrm{g} \%)$ & $13.37 \pm 1.53$ \\
\hline Leukocyte $(/ \mathrm{uL})$ & $5.670 \pm 1.725$ \\
\hline Platelet $\left(\mathrm{x} 10^{3} / \mathrm{uL}\right)$ & $187 \pm 74.45$ \\
\hline AST $(\mathrm{U} / \mathrm{L})$ & $86.70 \pm 52.49$ \\
\hline ALT $(\mathrm{U} / \mathrm{L})$ & $78.63 \pm 38.88$ \\
\hline Albumin $(\mathrm{g} / \mathrm{L})$ & $3.95 \pm 0.32$ \\
\hline Direct bilirubin $(\mathrm{mg} / \mathrm{dL})$ & $0.61(0.11-2.03)$ \\
\hline Total bilirubin $(\mathrm{mg} / \mathrm{dL})$ & $0.99(0.27-2.52)$ \\
\hline HCV RNA (IU/ml) & $3.14 \times 10^{6}\left(3.37 \times 10^{5}-3.91 \times 10^{7}\right)$ \\
\hline
\end{tabular}

AST, aspartate aminotransferase; $\mathrm{ALT}$, alanin aminotransferase; $\mathrm{HCV}$ RNA, hepatitis $\mathrm{C}$ virus ribonucleic acid

The metabolic characteristics of study subjects based on anthropometric data and laboratory (table 2). The median BMI of the study subjects was $23.76(16.00-24.8) \mathrm{kg} / \mathrm{m}^{2}$. The mean abdominal circumference of male subjects was $84.07 \pm$ $5.93 \mathrm{~cm}$ and female subjects was $75.23 \pm 5.46 \mathrm{~cm}$. The mean blood cholesterol level was $154.77 \pm 27.18 \mathrm{mg} / \mathrm{dL}$. The mean fasting blood sugar level was $101.03 \pm 18.80 \mathrm{mg} / \mathrm{dL}$. Fasting insulin levels were measured after the study subjects fasted for 12 hours and obtained a median of 12.88 (3.54 - 46.38) $\mathrm{mU} / \mathrm{L}$.

In this study, data collected on HCV RNA viral load levels and HOMA IR calculations based on fasting blood sugar and fasting insulin laboratory data from the medical records of 30 patients who were concluded. The number of $\mathrm{HCV}$ RNA viral loads in the subjects of this study was obtained median of 3.14 x106 IU/mL, with the lowest level 3.37 x105 $\mathrm{IU} / \mathrm{mL}$ and the highest level $3.91 \times 107 \mathrm{IU} / \mathrm{mL}$. This study showed the value of HOMA IR subjects with a median of 4.50 , with a minimum value range of 0.84 and a maximum value of 18.10 . 
Scatter plot of correlation between HCV RNA viral load level with HOMA IR value (Fig. 1) showed a positive linear relationship where the HOMA IR value tend to increase according to the increase in the number of HCV RNA viral load. Testing the significance level of the correlation between HCV RNA viral load and HOMA IR was carried out using the Spearman correlation test because the distribution of HCV RNA viral load data and HOMA IR value data were not normally distributed. Our study found that the result of Spearman correlation test showed a statistically significant positive correlation between HCV RNA viral load and HOMA IR ( $\mathrm{r}=0.537 ; \mathrm{p}=0.002)$.
Table 2 Metabolic Characteristic of Study Subjects

\begin{tabular}{lc}
\hline \multicolumn{1}{c}{ Variabel } & $\mathrm{n}=30$ \\
\cline { 2 - 2 } & Mean \pm SD or Median (min-max) \\
\hline BMI $\left(\mathrm{kg} / \mathrm{m}^{2}\right)$ & $23.76(16.00-24.8)$ \\
\hline Abdominal circumference $(\mathrm{cm})$ & $84.07 \pm 5.93$ \\
\hline Male & $75.23 \pm 5.46$ \\
\hline Female & $154.77 \pm 27.18$ \\
\hline Cholesterol (mg/dL) & $101.03 \pm 18.80$ \\
\hline FPG $(\mathrm{mg} / \mathrm{dL})$ & $12.8(3.54-46.38)$ \\
\hline Fasting insulin (mU/L) & $4.50(0.84-18.10)$ \\
\hline HOMA-IR &
\end{tabular}

BMI,body mass index; FPG, fasting plasma glucose; HOMA-IR, homeostasis model for insulin resistance

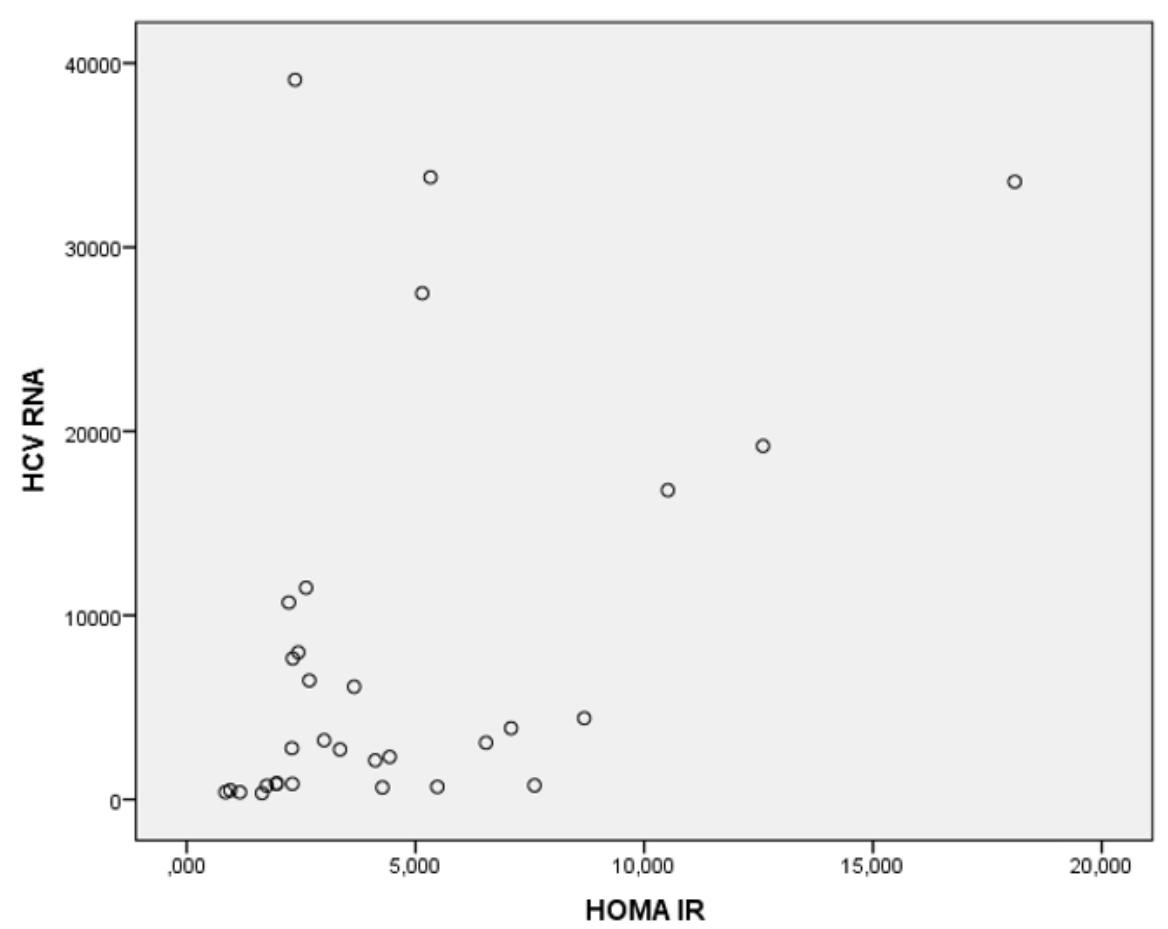

Figure 1. Scatter plot of correlation bet ween HCV RNA with HOMA-IR

\section{DISCUSSION}

In this study, we conducted 30 secondary data in the form of medical records of chronic hepatitis $\mathrm{C}$ patients who had met the inclusion and exclusion criteria with a percentage of 13 males (43.3\%) and 17 females (56.7\%), with more female subjects. This result consistent with previous studies (Umumararungu et al., 2017; Olmedo et al., 2017). The transmission route of $\mathrm{HCV}$ infection in this study was mostly through family relationships, followed by a history of surgery, blood transfusions, and having tattoos. Meanwhile, data from Direktorat Jenderal Pengendalian dan Penyehatan Lingkungan (Dirjen P2PL) Indonesia in 2007-2012 showed that the highest number of cases was found in men, with the ratio of men and women is $83 \%: 17 \%$ and the transmission route was mostly in intravenous drugs users, then in hemodialysis patients, family with hepatitis $\mathrm{C}$ infection, and patients with blood transfusion history (Dirjen P2PL, 2017).
Differences in the results of this study can be caused by the difference of study methods, the inclusion and exclusion criteria used.

The acute manifestations of $\mathrm{HCV}$ infection range from asymptomatic $(80 \%)$ to symptomatic $(20 \%)$, both mild and severe. Patients who suffer from mild symptoms as well as those who are asymptomatic tend to ignore this disease and fall into a chronic condition. This causes the majority of chronic hepatitis $\mathrm{C}$ patients aged > 50 years (Dirjen P2PL, 2017). In this study, the mean age of subjects was $50.90 \pm$ 7.17 years old. The results of this study are not much different from previous studies (Niu et al., 2016; Vagu et al., 2013; Barut et al., 2012). In our study, the result of the mean fasting blood glucose of study subjects consitent with the previous study (Li et al., 2019; Aksu et al., 2012). The mean was $101.03 \pm 18.80 \mathrm{mg} / \mathrm{dL}$. This result indicated that the 
population in this study already had higher fasting blood glucose level than normal. Fasting blood sugar in HCV infection increased due to several reasons (Parvaiz et al., 2011). HCV RNA components, especially core protein, NS3 , and NS-5, the presence of excess iron, and the occurrence of liver fibrosis in $\mathrm{HCV}$ infection were some of the things that affect fasting blood sugar, so that affect HOMA IR value as well. Increasing fasting blood sugar can lead to insulin resistance.

HCV RNA viral load is the number of hepatitis $C$ virus particles in every $1 \mathrm{ml}$ blood volume. Some of these virus particles are copies of the viral genetic material that circulates throughout the body. HCV RNA level of 800.000 $\mathrm{IU} / \mathrm{mL}$ was considered as a high viral load level (Parvaiz et al., 2011). Some studies reported that high HCV RNA viral load level was consistently associated with high rates of infectivity and poor response to therapy. It was also associated with the development of hepatocellular carcinoma, liver problems related to hepatitis $\mathrm{C}$ infection, and a strong predictor of the occurrence of chronic kidney disease complications (Lai et al., 2017). The median of our study subjects' HCV RNA viral load was $3.14 \times 10^{6} \mathrm{IU} / \mathrm{mL}$, with the lowest level was $3.37 \times 10^{5} \mathrm{IU} / \mathrm{mL}$ and the highest level was $3.91 \times 10^{7} \mathrm{IU} / \mathrm{mL}$. The median indicated that the study subjects had a high level of viral load.

HOMA IR was the most commonly used method of insulin sensitivity assessment in the hepatitis $\mathrm{C}$ population. HOMA IR was chosen by author because it has nearly the same sensitivity as the hyperinsulinaemic-euglycemic glucose clamp (HIEG) method, which is the gold standard for measuring insulin resistance. HOMA IR is easier to perform than HIEG, relatively inexpensive, and is widely available (Peres et al., 2013). In this study we used a cut-off value of $\geq$ 2.5 in accordance with the cut-off value used by a study conducted in Taiwan, taking into account the similarities in the demographic location with Indonesia, namely from Asia (Huang et al., 2014). Our study showed the median of HOMA IR was $4.50(0.84-18.10)$. It means that there was an incidence of insulin resistance in our study subjects. This result was supported by previous studies that chronic hepatitis $\mathrm{C}$ patients attend to have high value of HOMA IR (Aksu et al., 2012; Andrade et al., 2018; Gualerzi et al., 2018).

$\mathrm{HCV}$ infection causes insulin resistance through several mechanisms. One of the mechanisms is due to $\beta$-pancreatic cell damage and the presence of HCV RNA protein in the pancreatic tissue which causes direct cytopathic effects (Laskus et al., 1998). The components of the HCV RNA protein that are mainly involved in insulin resistance are the core protein, NS-3, and NS-5. HCV core protein induces TNF- $\alpha$ expression, decreases VLDL formation, increases lipogenesis and thus induces insulin resistance. The core protein also inhibits IRS-1, thereby decreasing GLUT4 regulation and increasing the release of $\mathrm{PKC}$, a gluconeogenic enzyme (El-Zayadi \& Anis, 2012). NS-3 protein has been shown to induce oxidative stress and increase NOX-2 regulation thereby accelerating the production of ROS and the release of pro-inflammatory cytokines such as TNF $\alpha$, TGF $\beta$, IL-6, and IL-8, which ultimately lead to liver fibrosis and insulin resistance (Bureau et al., 2001). NS-5A protein induces endoplasmic reticulum (ER) stress that leads to insulin resistance directly or indirectly by upregulation of the protein phosphatase $2 \mathrm{~A}$ (PP2A) cellular gene. PP2A itself decreases Akt regulation which results in inhibition of insulin signaling which leads to insulin resistance (Parvaiz et al., 2011).

The involvement of HCV RNA protein components in the incidence of insulin resistance was reflected in the relationship between HCV RNA viral load and HOMA IR. Our study showed a positive correlation with moderate strength between HCV RNA viral load and HOMA IR $(\mathrm{r}=0.537 ; \mathrm{p}=0.002)$. Previous studies also found statistically significant correlation between the two. A high HCV RNA viral load level associated with high HOMA IR value indicated the incidence of insulin resistance in chronic hepatitis C patients, supported by others study (Hsu et al., 2007; Moucari et al., 2008).

This study has limitations because conducted with a crosssectional design with one data collection chosen by author because it is relatively easy and the results are quickly obtained therefore unable to follow study subjects prospectively in analyzing the relationship between $\mathrm{HCV}$ RNA viral load and HOMA IR values in chronic hepatitis C patients. This study was conducted at the Gastrohepatology Outpatient Clinic Installation of Dr. Soetomo Teaching Hospital so that it did not describe the general public's situation.

\section{CONCLUSION}

The result of this study conclude that a positive moderate correlation was obtained between HCV RNA viral load and HOMA IR in chronic hepatitis $\mathrm{C}$ patients.

\section{CONFLICT OF INTEREST}

The authors declare there is no conflict of interest.

\section{REFERENCES}

Aksu HSZ, Kurtaran B, Onlen Y, Namiduru M, Inkaya AC, Kandemir O, et al. 2012. Association of insulin resistance, viral load, and adipokin levels with liver histology in patientswith chronic hepatitis C: an observational, multicenter study in Turkey. European Journal of Gastroenterology \& Hepatology 24(12):1393-1399.

Andrade VG, Yamashiro FS, Oliveira CV, Moreira A, Winckler FC, Silva GF. 2018. Insulin resistance reduction 
after sustained virological response with direct acting antiviral: Not every population improves. Arquivos de Gastroenterologia 55(3):274-278.

Barut S, Gunal O, Erkormas U. 2012. Serum ferritin In chronic hepatitis $\mathrm{C}$ patients during antiviral therapy and prediction of treatment response. Scandinavian Journal of Infectious Disease 44:761-765.

Bernsmeier C, Heim MH. 2009. Insulin resistance in chronic hepatitis C: mechanism and clinical relevance. Swiss Medical Weekly 139(47-48):678-684.

Bugianesi E, McCullough AJ, Marchesini G. 2005. Insulin resistence: a metabolic pathway to chronic liver disease. Hepatology 42:987-1000.

Bureau C, Bernard J, Chaouche N, Orfila C, Beraud M, Gonindard C, Alric L, Vinel JP, Pipy B. 2001. Nonstructural 3 protein of hepatitis $\mathrm{C}$ virus triggers an oxidative burst in human monocytes via activation of NADPH oxidase. J Biol Chem 276(25):23077-23083.

Caronia S, Taylor K, Pagliaro L, et al. 1999. Further evidence for an association between non-insulin-dependent diabetes mellitus and chronic hepatitis $\mathrm{C}$ virus infection. Hepatology 30:1059-1063.

Christen V, Treves S, Duong FH, Heim MH. 2007. Activation of endoplasmic reticulum stress response by hepatitis viruses up-regulates protein phosphatase $2 \mathrm{~A}$. Hepatol 46(2):558-565.

Direktorat Jenderal Pengendalian Penyakit dan Penyehatan Lingkungan (Dirjen P2PL). 2017. Panduan Singkat Tatalaksana Hepatitis C. Jakarta, Kementerian Kesehatan Republik Indonesia.

El-Zayadi AR, Anis M. 2012. Hepatitis C virus induced insulin resistance impairs response to anti viral therapy. World J Gastroenterol 18(3):212-224.

Gualerzi A, Bellan M, Smirne C, Tran Minh M, Rigamonti C, et al. 2018. Improvement of insulin sensitivity in diabetic and non diabetic patients with chronic hepatitis $\mathrm{C}$ treated with direct antiviral agents. PLOS ONE 13(12):e0209261.

Gowans EJ. 2000. Distribution of markers of hepatitis C virus infection throughout the body. Seminars in Liver Disease 20(1):85-102.

Hsu CS, Liu CJ, Liu CH, Wang CC, Chen CL, Lai MY, Chen PJ, Kao JH, Chen DS. 2007. High hepatitis C viral load is associated with insulin resistance in patients with chronic hepatitis C. Liver International.

Huang H, Chuang C, Hsieh Y, Chang T, Wei K, Shen C, Wu C, Tung S. 2011. Serum HCV RNA level is not associated with insulin resistance and metabolic syndrome in chronic hepatitis $\mathrm{C}$ patients with genotype 1 or 2 infection. Chang Gung Medical Journal 34(5):487-495.

Jafri SM, Gordon SC. Epidemiology of Hepatitis C. Clin Hati Dis 2018;12(5):140-142.

Jefferies M, Rauff B, Rashid H, Lam T, Rafiq S. Update on global of viral hepatitis and preventive strategies. World $\mathrm{J}$ of Clin Cases 2018;6(13):589-599.

Knobler H, Schihmanter R, Zifroni A, et al. Increased risk of type 2 diabetes in non-cirrhotic patients with chronic hepatitis C virus infection. Mayo Clin Proc 2000;75:355-9.

Lai TS, Lee MH, Yang HI, You SL, Lu SN, Wang LY, et al. High hepatitis $\mathrm{C}$ viral load and genotype 2 are strong predictors of chronic kidney disease. Kidney International 2017;92:703-709.

Laskus T, Radkowski M, Wang LF, Vargas H, Rakela J. Search for hepatitis $\mathrm{C}$ virus extrahepatic replication sites in patients with acquired immunodeficiency syndrome: specific detection of negative-strand viral RNA in various tissues. Hepatology 1998;28(5):1398-401.

Li Y, Wang X, Yu G, Sun H, Lv J, Chi X, Wu R, Gao X, Niu J. The association of hepatitis Cvirus infection status with serum glucose levels. BMC Gastroenterology 2019;19:86.

Machado MV, Cortez-Pinto $\mathrm{H}$. Insulin resistance and steatosis in chronic hepatitis C. Annals of Hepatology 2009;8(1):S67-S75.

Mangia A, Schiavone G, Lezzi G, et al. HCV and diabetes mellitus: Evidence for a negative association. Am J Gastroenterol 1998;93:2363-7.

Mason AL, Lau JY, Hoang N, et al. Association of diabetes mellitus and chronic hepatitis $\mathrm{C}$ virus infection. Hepatology 1999;29:328-33.

Mehta SH, Brancati FL, Sulkowski MS, et al. Prevalence of type 2 diabetes mellitus among persons with hepatitis $C$ virus infection in the United States. Ann Intern Med 2000;133:592-9.

Mohamed AA, Loutfy SA, Craik JD, Hashem AG, Siam I. Chronic hepatitis $\mathrm{C}$ genotype-4 infection: role of insulin resistance in hepatocellular carcinoma. Virology Journal 2011;8:496.

Mohamed HR, Abdel-Azziz MY, Zalata KR, Abdel-Razik AM. Relation of insulin resistance and liver fibrosis progression in patients with chronic hepatitis $\mathrm{C}$ virus infection. International Journal of Health Sciences 2009;3(2):186-187. 
Moucari R, Asselah T, Cazals-Hatem D, Voitot H, Boyer N, Ripault MP, Sobesky R, Martinot-Peignoux M, Maylin S, Nicholas-Chanoine $\mathrm{MH}$, et al. 2008. Insulin resistance in chronic hepatitis $\mathrm{C}$ : association with genotypes 1 and 4 , serum HCV RNA level, and liver fibrosis. Gastroenterology $134: 416-423$

Niu Z, Zhang PA, Tong YQ. 2016. Age and gender distribution of hepatitis $\mathrm{C}$ virus prevalence and genotypes of individuals of physical examination in WuHan, Central China. SpringerPlus 5:1557.

Olmedo DB, Precioso PM, Lugdero-Correia A, da Silva G, dos Santos AMG, Porto LC. 2017. Exposure source prevalence is associated with genderin hepatitis $\mathrm{C}$ virus patients from Rio de Janeiro, Brazil. Mem Inst Oswaldo Cruz 112(9):632-639.

Papatheodoridis GV, Chrysanthos N, Savvas S, et al. 2006. Diabetes mellitus in chronic hepatitis $\mathrm{B}$ and $\mathrm{C}$ : prevalence and potential association with the extent of liver fibrosis. J Viral Hepatitis 13:303-310.
Parvaiz F, Manzoor S, Tariq H, Javed F, Fatima K, Qadri I. 2011. Hepatitis C virus infection: molecular pathways to insulin resistance. Virology Journal 8:474.

Romero-Gomez M. 2006. Insulin resistance and hepatitis C. World J Gastroenterol 12(44):7075-7080.

Umumararungu E, Ntaganda F, Kagira J, Maina N. 2017 Prevalence of hepatitis $\mathrm{C}$ virus infection and its risk factors among patients attending Rwanda Military Hospital, Rwanda. BioMed Research International Volume 2017. Article ID 5841272.

Vagu C, Sultana C, Ruta S. 2013. Serum iron markers in patients with chronic hepatitis $\mathrm{C}$ infection. Hepatitis Monthly 13(10):e13136.

White DL, Ratziu V, El-Serag HB. 2008. Hepatitis C infection and risk of diabetes: a systemic review and metaanalysis. J Hepatol 49:831-844. 